\title{
刍议渡槽槽身现浇施工技术
}

\author{
朱海涛 \\ 广东省水利水电第三工程局有限公司 \\ DOI:10.18686/bd.v2i3.1292
}

[摘要] 渡槽在国税桥当中应用十分广泛, 在输水工程的建设中, 其也是不容忽视的一个组成部分。因此在施工中加大对 大型渡槽槽身施工技术的研究也具有十分积极的作用。只有对这一技术进行更为深入的研究, 才能更好地保证其应用的质 量与效果。

[关键词] 大型渡槽;槽身;施工技术;进展

渡槽通常又被称为国税桥。前期主要借助架空水槽将 水流输送至河流或公路对面,在排沙、防洪和灌溉方面都有 着非常广泛的应用。大型渡槽可以保证输水功能,甚至渡槽 在很多水利工程中都发挥了非常显著的作用。在施工中其 结构也相对比较复杂, 因此我们需要对渡槽槽身现浇施工 技术进行全面研究。

\section{1 渡槽简介}

渡槽可以非常好地将水流输送到河流的对面, 从而可 以保证地势复杂地区的供水, 将地势对水流的负面影响降 至最低水平。同时还能够为人们保证更为充足的水源供应, 因此在输水工程中应用较为普遍。渡槽若按照施工方法来 划分主要有两种,一种是预制装配式结构,一种是现浇整体 式结构。前者在槽身施工的过程中可以更好地控制资金成 本和劳动及材料成本, 此外这种施工方法还可有效提高施 工的速度和效率, 在质量控制方面难度也不是很大。但是这 种形式也存在着一定的不足, 无法找到完全适合的预制场 所。槽身的体积较大, 所以无法对其进行移动和翻转, 吊装工 作无法正常开展。因此这种方式一般应用在小规模的施工 之中。大型渡槽施工中普遍应用整体现浇的施工方式。

\section{2 工程简介}

某工程在工程建设中主要要维修和改造 7 段出险护 岸, 同时还要将三座原建码头进行拆除处理,对护岸结构进 行有效修复, 还要对河道沿岸废弃的穿堤涵闸进行封堵处 理,对水桥进行拆除重建, 还要对闸桥桥面以及桥上的栏杆 进行科学维护, 还要对沿岸进行内涝改造, 工程难度较大。

\section{3 现浇整体式渡槽槽身施工工艺分析}

3.1 钢筋制安

在工程建设和施工中, 为了更好地确保槽身的质量及 性能, 施工人员一定要科学选择钢筋的规格以及钢筋的材 质, 此外还要对施工的技术规范及标准要求予以全面掌握, 进而选择合适的焊条。钢筋和焊条在进场前一定要有质量 检验报告以及合格证书, 必要时还要对其进行性能检验, 只 有这样, 才能更好地保证槽身建设的质量。底板部分的钢筋 用量较大,且穿插的难度较大,复杂性高,一定要严格遵照工 程施工的工序对其进行处理。在工程施工前还要在底模的
指定位置设置钢筋为直线, 从而确定钢筋绑扎的具体位置。 在钢筋绑扎施工中, 中间部分的绑扎可以采用梅花形的设 计方式, 外围两行交点位置也要按照施工要求进行科学绑 扎, 而若是双向受力钢筋则应在钢筋绑扎中采取满绑的方 式。在绑扎底排钢筋时, 应使用混凝土垫块垫起钢筋, 同时还 要采用梅花形对钢筋进行处理, 进而更好地确保保护层的 厚度。在完成下层钢筋的绑扎施工后还要正确摆放钢筋马 登。下层与底部的钢筋应保证其牢固性, 在马登上完成定位 绑扎后才能对上层钢筋进行绑扎施工。底板钢筋安装技术 后, 施工人员应严格按照图纸的要求对边墙立筋进行有效 的焊接,后对纵向钢筋开展绑扎处理。顶板钢筋安装施工中, 其施工方法与底板完全一致。在工程施工中只有确保钢筋 位置偏差合理,才能更好地提升槽身建设的质量及水平。钢 筋位置允许的偏差如表 1 所示:

表 1 钢筋位置允许的偏差

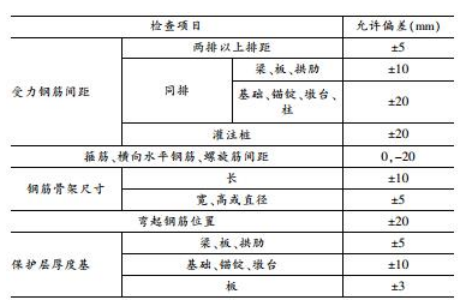

3.2 模板制作与安装

在模板施工前必须要做好准备工作, 对施工现场的具 体情况要充分了解, 同时还要做好测量放线工作, 从而确定 渡槽位置和中心线的具体设置。此外还要在这一过程中确 定模板定位的基准,确定标高, 从而更好地为工程的建设与 施工提供便利条件。底模侧模的施工中我们可以采用订制 钢模, 沿着渡槽的槽身外边线来完成拼装工作, 此外还要将 模板缝隙用双面胶条填充严实。在钢模安装施工结束后, 还 要完成模板高程测量工作。此外还要在施工中结合施工图 纸的要求订制内模和外模以及一套异型钢模板。钢模板选 择中一定要充分考虑分缝的技术要求, 同时还要关注模板 的刚度以及尺寸等。单元块浇筑的模板一般是由标准块和 异型块拼装组成。

3.3 渡槽槽身混凝土施工工艺 
要合理选择混凝土级配, 要严格根据设计图纸的要求 对混凝土的配比进行有效的调整,此外,还要对最低胶凝材 料的具体使用量、混凝土的水灰比以及坉落度等进行严格 控制, 经监理工程师签字验收后才能施工。若工程建设中出 现变更情况还要及时获得监理工程师的认可。

\section{4 仓面施工准备}

仓面施工前,一定要首先做好测量放样环节, 此外还要 对已经完成浇筑的混凝土面和地基进行全面清理, 此外还 要保证施工前安装预埋工作准确到位。上述工作结束后还 应对其进行全面的检查, 此外还要对检查结果进行详细的 记录。

\section{5 验槽测量放样与基底清理}

在验槽测量放样时可采用专业设备测量放线, 验槽测 量放样必须要在仓面施工前完成, 同时还要对上一道工序 的质量进行严格检查,确保工程后期建设的顺利进行。在基 底清理中应对岩面上的破损部分、泥土以及出现松动的岩 石以及生锈的部分进行全面的清理。陈旧混凝土面施工中 还可采用高压水枪冲毛或人工丵毛的方式去处理, 进而保 证结构表面的质量。

3.6 止水、伸缩缝安装

在止水施工中,一定要严格遵照技术要求与规范,必要 时还应在仓面上止水位置设置双止水带, 进而更好地保证 止水安装的质量。在止水安装过程中,可采取模板嵌固的方 式,此外还要严格控制安装误差。在混凝土浇筑施工中还要 采取有效的保护措施,避免影响工程的施工质量。伸缩缝施 工的过程中,一定要充分参照施工图纸和技术要求, 采取有 效措施处理麻面和蜂窝, 此外还要对外露的铁件进行全面 清理,然后才能进行止水、防水和垫层施工。

3.7 模板调整施工

模板安装施工技术后,要仔细检查模板尺寸、设置的位 置、平整度和标高等重要参数。若在检查的过程中发现与设 计要求存在较大差异, 则应及时采取有效措施对其进行科 学调整, 进而更好地保证不同形式的混凝土梁以及柱的模 板能够满足施工的规定及要求。此外还要采取有效措施对
模板内外拉撑进行科学加固。模板自身必须要具备较强的 稳定性,刚度也应满足施工要求。此外, 还要对各模板之间的 㖓隙进行科学填充, 保证模板平整度和严密度, 进而有效避 免漏浆问题。

3.8 工作面清理、冲洗

止水片、钢筋模板和预埋工作全部结束之后, 一定要对 上述环节进行严格的自检, 在施工队自检后还要做好记录 工作,处理好工作面的清理工作,保证工作面的整洁。在清理 时可采用高压水枪进行冲洗处理, 之后再采用有效的措施 将仓面上的水排净。在验收合格后才能开展接下来的操作 与施工。

\section{9 混凝土浇筑施工分析}

在开展槽身混凝土浇筑施工的过程中, 我们可以借助 混凝土输送泵来将混凝土输送至仓内, 浇筑施工中通常采 用水平分层浇筑的施工方式。首先对底板进行浇筑施工,施 工中要保证浇筑的连贯性。车去抢购混凝土浇筑中采取对 称浇筑的形式,更好地保证骨料分布的均匀度。在浇筑施工 结束后还应采取有效措施对混凝土进行酒水或覆盖养护, 在混凝土强度满足施工要求后可以将模板拆除。

\section{4 结束语}

当前,在我国经济和社会的发展中,水利工程所占的地 位越来越重要。输水线路由于其长度较大,所以穿过复杂地 质条件的可能性较大, 而为了更好地保证输水的质量, 渡槽 在输水工程中得到了广泛的应用。渡槽槽身现浇施工是目 前较为常见的施工形式, 因此施工中必须要对每一个施工 流程进行严格控制, 同时还要科学地对施工进行有效的监 督与管理,进而更好地保证工程建设的质量及效果。

\section{参考文献:}

[1]陈开举.对大隆总干渠渡槽槽身施工工艺及质量控 制探讨[J].中国新技术新产品,2017,(23):66-67.

[2]陈玉英. 大型预应力混凝土矩形渡槽槽身结构型式 研究[J].郑州大学学报(工学版),2017,38(05):61-64.

[3] 宁进步,渡槽槽身现浇施工技术[ J]. 建筑技术开发, 2018,45(04):28-30. 